\title{
Gebelikte Folik Asit, B12 Vitamini, D Vitamini ve İyot Destekleri Kullanmak Gerekli Midir? Olası Riskler
}

\author{
Is It Necessary Folic Acid, Vitamin B12, Vitamin D and Iodine Supplementation in Pregnan- \\ cy? Posssible Risks
}

Hilal ŞIMSŞEK ${ }^{1}$, Yasemin KARAAĞAÇ ${ }^{2}$, Esra TUNÇER ${ }^{1}$, Hülya YARDIMCI ${ }^{1}$

\author{
${ }^{1}$ Ankara Üniversitesi, Sağlık Bilimleri Fakültesi, Beslenme ve Diyetetik Bölümü, Ankara, Türkiye \\ ${ }^{2}$ İzmir Kâtip Çelebi Üniversitesi, Sağlık Bilimleri Fakültesi, Beslenme ve Diyetetik Bölümü, İzmir, Türkiye
}

\begin{abstract}
Özet
Gebelik sürecinde artan gereksinimler dolayısıyla; özellikle bazı mikro besin ögelerinin besin desteği olarak alınması ve böylece yetersizlik ile ilişkili risklerinin en aza indirilmesi, maternal ve fetal sağlığın korunmasında büyük öneme sahiptir. Gebelikte, besin ögelerinin ciddi veya orta düzeyde yetersizliğinde, hayat kurtarıcı nitelikte olan destekler; hafif yetersizlik veya maternal depoların yeterli olduğu koşullarda, çeşitli riskleri de beraberinde getirmektedir. Doğumsal anomalilerin önlenmesinde etkisi kanıtlanmıș olan folik asitin maternal dönemde fazla alımı durumunda kanserojeniteyi tetikleyebileceği, çinko emilimini olumsuz etkileyebileceği, $\mathrm{B}_{12}$ vitamini eksikliğinin tanısında ve tedavisinde gecikmelere yol açabileceği, çocukluk çağı astım, alerji riski ile ilişkili olabileceği görülmüştür. Eksikliği fetal anomaliler ile ilişskilendirilen bir diğer vitamin olan Bı2'nin toksik etkisi bildirilmemekle birlikte literatür taramasında fazla alımı durumunda alerjik reaksiyonlar gösteren bir vaka raporuna rastlanmıştır. Yenidoğan hipokalsemisi ve raşitizmin önlenmesinde etkili D vitamini desteğinin fazla alımı teratojen etki gösterebilir. İyot yetersizliği ile ilişkili kretenizm gibi hastalıkların önlenmesinde etkili olan iyot desteğinin fazla alımının gebenin tiroid disfonksiyonuna, gebelikteki subklinik ve aşikâr hipotiroidizm prevalansında artışa yol açabileceği ve bebeğin psikomotor gelişimini olumsuz etkileyebileceği belirtilmiştir. Gebelikte önerilen dozlarda besin desteklerinin kullanımı uygundur ancak yetersizliğin önlenmesi kadar fazla alım konusunda da dikkatli olunmalıdır. Bu derlemede; gebelikte yaygın olarak kullanılan folik asit, $\mathrm{B}_{12}$ vitamini, $\mathrm{D}$ vitamini ve iyot besin desteklerinin fazla alımına ilişkin riskler tartışılmıştır.
\end{abstract}

Anahtar Kelimeler: Gebelik, Besin desteği, Folik asit, B12 vitamini, D vitamini, İyot

\begin{abstract}
Due to the increasing nutritional requirements in the pregnancy, taking certain micronutrients as dietary supplements and thus minimizing the risks associated with deficiency is of great importance in the protection of maternal and fetal health. In pregnancy, dietary supplements are vital in severe or moderate deficiency of nutrients, also bring various risks in conditions of mild deficiency or adequate maternal nutrient storage.The effect of folic acid supplementation on prevent congenital anomalies, has been proven. In maternal period, excessive intake of folic acid may cause carcinogenicity, negatively affect the absorption of zinc, lead to delays in the diagnosis and treatment of vitamin $\mathrm{B}_{12}$ deficiency, and may be associated with the risk of childhood asthma and allergy. Vitamin $B_{12}$ is another vitamin whose deficiency is associated with fetal anomalies. Although the toxic effect of vitamin $B_{12}$ is not reported, a case report showing allergic reactions was found in the literature review in case of excessive intake. Vitamin D, which is beneficial in the prevention of neonatal hypocalcemia and rickets, excessive intake of the supplement may be a teratogenic effect. Iodine supplement is effective in preventing diseases such as cretinism associated with iodine insufficiency. However, it has been stated that excessive intake of iodine supplement may lead to an increase in the prevalence of thyroid dysfunction of the pregnant woman, subclinical and overt hypothyroidism during pregnancy and negatively affect the psychomotor development of the baby. The use of nutritional supplements at the recommended doses during pregnancy is appropriate, but attention should also be paid to excessive intake as well as prevention of insufficiency. In this review, the risks of excessive intake of folic acid, vitamin $\mathrm{B}_{12}$, vitamin $\mathrm{D}$, and iodine supplements used in pregnancy are discussed.
\end{abstract}

Keywords: Pregnancy, Dietary supplements, Folic acid, Vitamin B12, Vitamin D, Iodine

Yazışma Adresi: Hilal Şi̇MŞEK, Ankara Üniversitesi, Sağlık Bilimleri Fakültesi, Beslenme ve Diyetetik Bölümü, Ankara, Türkiye

Telefon: +90 54354188 99, Mail: hllsimsek@ankara.edu.tr

ORCID No (Sirasıyla): 0000-0002-2744-1610,0000-0002-2757-2485, 0000-0001-7151-842X, 0000-0002-2664-4176

Geliş Tarihi: 28.11 .2020

Kabul Tarihi: 30.01 .2021

DOI: $10.17517 / \mathrm{ksutfd} .832401$ 


\section{GIRIŞ}

Vitamin ve minerallerden oluşan mikro besin ögeleri, fizyolojik reaksiyonlar için gerekli bir grup element ve bileşiği kapsamaktadır. Mikro besin ögeleri; hücresel sinyal yolakları, proliferasyon, homeostazi gibi birçok metabolik süreçte yer almaktadır. Bu sebeple; mikro besin ögelerinin gebelik sürecinde yeterli oluşu, optimal fetal gelişim için elzemdir $(1,2)$. Yeterli ve dengeli bir beslenme planı, mikro besin ögelerini genellikle yeterli miktarda sağlamaktadır. Bununla birlikte; özellikle gebeler gibi besin ögeleri gereksinimleri artmış risk grupları söz konusu olduğunda, mikro besin ögesi yetersizlikleri dünya çapında önemli bir halk sağlığı sorunu oluşturmaktadirlar (3).

Prekonsepsiyonel veya prenatal maternal mikro besin ögesi eksiklikleri, yalnızca olumsuz gebelik sonuçlarıyla yakından ilişkili olmakla kalmayıp; aynı zamanda kronik hastalıkların gelişimsel kökeninde de rol alabilmektedir $(4,5)$. Fetal gelişim sürecinde önemli besin ögelerinin yetersizliği fetal dokuların yeniden programlanmasına yol açarak bebeğin sonraki yaşamını da etkileyebilir (6).

Gebelikle birlikte annede görülen fizyolojik değişimler ve fetüs, plasenta ve gebelik ile ilgili dokuların gelişimi enerji, makro ve mikro besin ögeleri gereksiniminde artışa neden olmaktadır (7). Dolayısı ile gebe ve gebe olmayan kadının mikro besin ögesi gereksinimleri birbirinden farkl1lıklar göstermektedir (8). Bu sebeple, Dünya Sağlık Örgütü (DSÖ) anne ve çocuk sağlı̆̆ını iyileştirmeyi amaçlayan temel beslenme programları kapsamında, gebeler için hedeflenen demir ve folik asit desteğini içeren müdahale planları oluşturmuştur (9).

Gebelik sürecinde, mikro besin ögelerinin eksikliği kadar; fazla alımları da maternal ve fetal sağlık açısından önemlidir. Bu derlemede, gebelikte besin desteği olarak kullanımı önerilen bazı vitamin ve minerallerin fazla alınması durumunda oluşabilecek sağlık riskleri hakkında bilgi verilmesi amaçlanmıştır.

Folik Asit: Besinlerde doğal olarak oluşan ve suda çözünen bir organik bileşen olan folat (B9), B grubu vitaminleri arasında yer alır. Folik asit ise folatın sentetik şeklidir. Folat, RNA ve DNA sentezi, transaminasyon ve metilasyon süreci için önemli olan birçok tek karbon transfer reaksiyonunda kofaktör olarak görev alır. Hücre bölünmesi, doku büyümesi için gereklidir (10). Dolayısı ile, gebe olmayan kadınlara kıyasla gebe kadınların folat gereksinimi 5-10 kata çıkabilmekte, bu durum da gebe kadınlarda folat eksikliği riskini arttırmaktadır (11). Folik asit eksikliği megaloblastik anemi, hiperhomosisteinemi, DNA replikasyonu ve hücre bölünmesinde bozulmalara neden olmaktadır $(10,12)$. Gebelerde artan folat gereksinimini tek başına diyetle karşılamak zor olduğu için folik asit desteği önerilmektedir (13).

Gebelikte görülen folat eksikliği doğumsal defektlerle ilişkilidir. Bununla birlikte, folik asit desteğinin fetüsü nöral tüp defektinden (NTD) koruduğu bilinmektedir (14). Nöral tüp defektinin etiyolojisi tam olarak bilinmemekle birlikte metiyonin eksikliği ve tek karbon metabolizmasındaki bo- zukluklar olası nedenler arasındadır $(15,16)$. Ayrıca, gebe kadınlarda folat desteğinin spontan abortus riskini azalttığ 1 bildirilmiştir (17). Düşük folat alımı, hücre bölünmesinde azalma, metilasyon reaksiyonlarının bozulması, inflamatuar sitokin üretimi, oksidatif stres düzeyi ve apoptozis artışı ile ilişkilidir ve bunlar embriyonun gelişimini etkileyebilmekte$\operatorname{dir}(18)$

Yeterli folat alımı fetüsün kardiyovasküler sisteminin normal gelişimi için gereklidir. Gebelikte folik asit veya folik asit içeren multivitaminlerin kullanılması ile konjenital kalp anomalilerinin yaklaşık \% 40'ının önlenebileceği saptanmıştır (19). Çin'de yapılan bir kohort çalışmasında, folik asit desteği almayan ve düşük diyet folat alımı olan kadınların, bebeklerinde yaklaşık iki kat artmış konjenital kalp defektleri riski olduğu bildirilmiştir (20). Yetersiz folat 5-metil-tetrahidrofolatın (5-MTHF) re-metilasyonunu önler ve homosistein birikmesine yol açar (21). Aşırı homosistein kardiyak nöral krest hücre göçü, farklılaşması, dağılımı, hücre döngüsü ilerlemesinde bozulmaların sonucunda konjenital kalp defektleri oluşabilir (22).

Folat eksikliği nükleotid biyosentezinde ve metilasyon reaksiyonlarında anormalliklere yol açabilir, DNA sentezi, onarımı ve metilasyonunu etkileyerek hücrenin genomik instabilitesine neden olabilir (23). Bu durumla ilişkili olarak folik asit yetersizliğinin kanser gelişiminde rol oynayabileceği düşünülmektedir (24). Gebelik öncesi ve sırasında maternal folik asit desteğinin, bebeklerde çocukluk çağ ${ }_{1}$ lösemi riskine karşı koruma sağlayabileceği de belirtilmiştir (23). Ancak yetersizliğinin oluşturabileceği birçok sağlık sorununun yanı sıra fazla alındığında da istenmeyen durumların oluşması söz konusu olabilmektedir.

Gebelik döneminde folik asit fazla alımına ilişkin risklerden biri karsinojenitedir (21). Artmış folat durumunun meme ve prostat kanseri riski ile ilişkili olabileceğini bildiren yayınlar mevcuttur $(25,26)$. Folat müdahalesinin zamanlaması ve dozu, folatın karsinogenezdeki rolünden sorumlu görünmektedir. Folik asit desteği, normal dokulardaki tümörlerin gelişimini baskılarken, zaten büyüyen tümörlerin gelişimini ve ilerlemesini hızlandırabilir (21). Bu nedenlerle folatın hem yetersizliğinin hem de fazlalığının önlenmesinin kanser gelişme riskinin azaltılmasında yararlı olabileceği düşünülmektedir.

Folatın fazlalığı durumunda olası bir diğer risk, çinko emilimi üzerindeki olumsuz etkileridir (21). Çinko, gen ekspresyonu, protein sentezi, hücre bölünmesi, büyüme ve bağ1şıklık sisteminde görev alır. Çinko eksikliğinde immünolojik, nörolojik ve gastrointestinal fonksiyonların bozulması gibi çeşitli problemler görülebilir. Gebeler çinko eksikliği açısından risklidir, çünkü gereksinimleri artmaktadır (27). Folik asit ve çinkonun mide asidik pH’sinde çözünmez kompleksler oluşturabileceği düşünülmektedir (21). Bu kompleksler duodenumun yüksek pH'sinde çözünebilir, ancak çeşitli patolojik durumlar, duodenumun pH'sinin 6.0'nın altında kalması, çinko-folat komplekslerinin çözünmesini engeller ve çinko emilimini bozar (28). Folik asit desteğinin çinko emi- 
limi üzerine etkisi konusundaki sonuçlar çelişkilidir; çinko emilimini azaltabileceğini bildiren çalışmalar olmakla birlikte herhangi bir olumsuz etkisi olmadığını bildiren çalışmalar da mevcuttur $(21,29,30)$.

Yüksek folik asit desteğinin potansiyel bir diğer riski folat ve $B_{12}$ vitamini arasındaki ilişkidir. Bu durum metil tuzağ hipotezi ile açıklanabilir (21). 5,10-metilen tetrahidrofolatın (5,10-MTHF), 5-MTHF dönüşümü metilen tetrahidrofolat redüktaz ile katalizlenir ve bu reaksiyon geri dönüşümsüzdür. 5-MTHF'nin folat-bağımlı reaksiyonlara katılabilmesinin tek yolu, $B_{12}$-bağımlı metiyonin sentaz enzimi üzerindendir. $B_{12}$ vitamini eksik hücrelerde folat varlığı normaldir; bununla birlikte folat, metilasyon döngüsü ve DNA biyosentezine katılamayan 5-MTHF olarak tutulur; bu durum folat psödoeksikliği (pseudodeficiency) olarak adlandırılır $(21,31)$.

İntramusküler verilen $B_{12}$ vitamini, metiyonin sentazı aktive eder, metilasyon döngüsünü ve DNA sentezini ve miyelinasyonu yeniden başlatır ve anemiyi önler. Yüksek doz folik asit desteği aneminin tedavisinde etkili olabilir. Ancak folik asit desteği, B12-bağımlı metiyonin sentaz tarafından bloke edilen metilasyon döngüsünü tekrar başlatamaz, dolayısı ile oluşan nöropatiyi etkilemez. Bu nedenle folik asit destek tedavisi, $B_{12}$ vitamini eksikliğinin neden olduğu hematolojik değişiklikleri maskeleyebilir ve nörolojik semptomların gecikmiş tanı ve tedavisine yol açabilir $(21,32)$.

Folik asitin fazlalığına ilişkin tartışılan konulardan biri de otizm riskidir. Çalışmaların bir kısmı gebelik öncesinde ve sırasında folik asit desteğinin otizm riskini azalttığını, bir kısmı ise yüksek dozda folik asit desteğinin otizm riskini arttırdığını ve bilişsel gelişimi olumsuz yönde etkilediğini belirtmektedir (33). Gebelikte folik asit desteği ile nörogelişim/ otizm arasındaki ilişkiyi inceleyen toplam 22 araştırmanın dahil edildiği bir sistematik derlemede, 15 çalışmada nörogelişim/otizm üzerinde folik asit desteğinin yararlı etkileri bulunduğu, altı çalışmada istatistiksel olarak anlamlı farklılık saptanmadığı, bir çalışmada ise gebelikte $>5 \mathrm{mg} /$ gün folik asit desteğinde olumsuz bir etki (istatistiksel anlamlılık olmamakla birlikte, gecikmiş psikomotor gelişim riski) belirlendiği bildirilmiştir (34).

Gebelikte yüksek doz folik asit desteğine ilişkin diğer endişeler çocukluk çağı astım ve alerji riskidir. Bir kohort çalışması sonucunda annenin gebelik döneminde yüksek folat ve $\mathrm{B}_{12}$ vitamini düzeylerinin, bebeklerde atopik dermatit prevalansı ile ilişkili olduğu bildirilmiştir (35). Güncel bir meta-analizde maternal folik asit alımının, bebekte astım riskini arttırabileceği ve doz-yanıt ilişkisinin doğrusal olduğu belirtilmiştir (36). Avustralya'da yapılan bir kohort çalışmasında gebeliğin sonlarında (30-34. hafta) folik asit desteği kullanımının, doğan çocuğun 3.5 ve 5.5 yaşında astım riskini arttırdığı saptanmıştır (37). Çin'de yapılan bir vaka-kontrol çalışmasında gebelikte yüksek doz folik asit desteği kullanımının (>72,000 mcg/gün); bebeğin astım riskini arttırdığı, düşük doz (<36,000 mcg/gün) kullanımının ise bebeğin astım riskinde azalma ile ilişkili olduğu bildirilmiştir (38). Bebeklerde folik asit kaynaklı görülen astım riskinin mekanizması he- nüz net olarak bilinmemektedir (36). Ayrıca maternal folik asit desteği ile astım riski arasındaki ilişkiyi desteklemeyen çalışmalar da literatürde mevcuttur. Amerika'da yapılan bir kohort çalışmasında, gebeliğin bir önceki ayında ve/veya ilk trimesterinde folik asit desteği alımının, çocuğun altı yaşındaki astım riski ile ilişkili olmadığı saptanmıştır (39). Benzer bir sonuç Hollanda'da yapılan bir kohort çalışmasında bildirilmiştir; maternal diyette folik asit desteğinin, bebeklerde hırıltılı solunum ve astım dahil olmak üzere atopik sonuçların artmış riski ile ilişkili olmadığı saptanmıştır (40). Yapılan başka bir kohort çalışmasında, prenatal folik asit desteğinin çocuklarda (1-8 yaş) solunum ile ilgili problemler veya alerjik sonuçlarla ilişkili olmadığı belirlenmiştir (41). Bir kohort çalışmasında, üçüncü trimesterde daha yüksek dozlarda ek olarak alınan folik asitin, erken çocukluk döneminde (bir yaş) egzama ile ilişkili olsa da, duyarlılık gibi diğer alerjik sonuçlar üzerinde herhangi bir etkisi saptanmamıştır (42). Maternal folik asit desteği ile astım ve alerji riski arasındaki ilişkinin detaylı incelenmesi, doz-yanıt, zamanlama konularının belirlenmesi ve olası mekanizmaların aydınlatılması yararlı olacaktır.

Anne ve bebek sağlığı açısından folik asit oldukça önemlidir. Bununla birlikte, daha az sayıda olsa da, yüksek doz folik asit desteğinin olumsuz etkilerini gösteren çalışmalar da mevcuttur. Uterus gelişimi sırasında folik aside aşırı maruz kalmanın potansiyel sağlık etkileri hakkındaki artan endişelere yanıt verebilecek araştırmaların yapılması gerekmektedir. Bu bağlamda etik konular, sağlık sonuçlarına diğer besin ögelerinin olası etkileri göz önünde bulundurulmalıdır.

Dünya Sağlık Örgütü, mümkünse gebelik öncesinden başlayarak, gebelik sürecinde $400 \mathrm{mcg} /$ gün folik asit desteği önermektedir (9). Avrupa Gıda Güvenliği Otoritesi (EFSA) ve TÜBER'de önerilen yeterli folat alım düzeyi gebeler için $600 \mathrm{mcg} /$ gün'dür $(8,10)$. Folatın doğal besinlerle alımı güvenlidir ve yüksek miktarda alındığında yan etkisi bildirilmemiştir. Dolayısı ile, EFSA tolere edilebilir üst alım düzeyini sentetik form olan folik asit alımına göre belirlemiştir. Gebeler için üst alım düzeyi 1000 mcg/gün'dür (10).

B12 Vitamini (Kobalamin): Gebelikte gereksinimi artan bir diğer vitamin $\mathrm{B}_{12}$ vitaminidir. Yaşamın ilk yıllarında merkezi sinir sisteminin gelişimi ve miyelinasyonu için $\mathrm{B}_{12}$ vitamini gereklidir (43). B12 vitamini, birçok hücresel süreçte görev alan B grubu vitaminlerinden biridir ve vücutta iki önemli reaksiyonda koenzim olarak gereklidir. Bunlardan biri, metilmalonil-koenzim A (CoA) mutaz tarafından metilmalonil-CoA'nın süksinil-CoA'ya dönüşümüdür. Diğeri ise homosisteinin metiyonine dönüşümündeki rolüdür (44).

$\mathrm{B}_{12}$ vitamini maya içermedikçe, vitamini üreten mikrobiyal fermantasyona (örneğin, bira) maruz kalmadıkça veya besin $\mathrm{B}_{12}$ vitamini ile zenginleștirilmedikçe (örneğin, zenginleştirilmiş hazır kahvaltılık tahıllar) yaygın olarak tüketilen bitkisel besinlerin normal bir bileşeni değildir (44). Başlıca diyet kaynakları kırmızı et, tavuk, balık, kabuklu deniz ürünleri, süt, yoğurt, yumurta, peynir ve karaciğerdir (45). $\mathrm{Bu}$ nedenle özellikle vejetaryen gebelerin $\mathrm{B}_{12}$ vitamin eksikliği açısından risk altında olabilecekleri unutulmamalıdır (46). 
Diyetteki yetersizlik, emilim ve metabolizmadaki bozukluklar (intrinsik faktör eksikliği, gastrit, çölyak, crohn, gastrik rezeksiyon gibi) ve bazı ilaçların (proton pompa inhibitörleri ve metformin) kullanımı sonucunda $B_{12}$ vitamini eksikliği görülebilmektedir (47). $\mathrm{B}_{12}$ vitamin eksikliğinin en sık görülen klinik durumu pernisiyöz anemidir (44). B12 vitamini eksikliği, prekürsör maddelerin birikmesine (hiperhomosisteinemi ve metilmalonik asidemi) bağlı makrositik anemi, nörolojik fonksiyon bozukluğu ve biyokimyasal anormalliklere neden olur. Ayrıca gebelikte hiperhomosisteinemi durumu, gebelik yaşına göre küçük doğum, erken ve tekrarlayan düşük, intrauterin büyüme geriliği, düşük doğum ağırlı̆̆1, gestasyonel hipertansiyon, nöral tüp defektleri, erken doğum dahil olmak üzere, birçok olumsuz sonuç için daha yüksek bir risk ile ilişkilendirilmiştir (48-52).

Sağlıklı bireylerde besinden veya besin desteğinden fazla miktarda $B_{12}$ vitamini alımı ile ilişkili herhangi bir olumsuz etki bildirilmemiştir. Hastalara verilen 1-5 mg/gün arasında $B_{12}$ vitamini dozlarının uzun dönem oral veya parenteral uygulamasında yan etki görülmemiştir (44). B12 vitamini ile teratojenite, doğurganlık veya doğum sonrası gelişim üzerinde olumsuz etkiler ile ilgili kanıta rastlanmamıștır $(44,45)$. B12 vitamininin in vitro veya in vivo olarak kanserojen veya genotoksik olduğu bulunmamıştır. Bu nedenle, tolere edilebilir üst alım düzeyinin türetilmesi için temel olarak kullanılabilecek olumsuz etki saptanmamıştır (44). Ancak, literatürde rastlanan bir vaka raporunda, şiddetli pernisiyöz anemisi olan 24 yaşında bir kadının günlük $1 \mathrm{mg}$ siyanokobalamin dozları ile tedavi edildiği; toplam $12 \mathrm{mg}$ dozdan sonra akne, çarpıntı, anksiyete, akatizi, yüzde kızarıklık, baş ağrısı ve uykusuzluk geliştiği bildirilmiştir. İlacı durdurduktan iki hafta sonra semptomları iyileşmiştir. Sonuçta, kobalamin toksisitesinin bu semptomlarının beklenmedik ve olağandışı olmasına rağmen, herhangi bir ilacın verilmesinin tamamen güvenli olmadığını hatırlamak gerektiği vurgulanmıştır (53).

Yetersiz $\mathrm{B}_{12}$ vitamini alımının folat metabolizmasını bozabileceği ve fetal gelişimi (NTD), nörolojik fonksiyonları (demiyelinizasyon) etkileyen anormallikler ile ilişkili olabileceği göz önünde bulundurulmalı; gebelerde $\mathrm{B}_{12}$ vitamin eksikliği önlenmelidir. Bu kapsamda gebenin yeterli ve dengeli beslenmesini sağlamak, annenin ve bebeğin sağlı̆̆ını korumak-geliştirmek açısından bu özel dönemde diyetisyene başvurulması, besin tüketimlerinin değerlendirilmesi uygun olacaktır. B12 vitaminin toksisitesi konusunda sınırlı veri olmakla birlikte özellikle besin desteği olarak kullanımında hekime danışılması olumsuz sonuçların önlenmesi açısından doğru bir yaklaşımdır.

Dünya Sağlık Örgütü ve Gıda ve Tarım Örgütü tarafından gebelikte önerilen $B_{12}$ vitamini referans alım düzeyi 2.6 mcg/gündür (54). Gebeler için TÜBER ve EFSA'da önerilen $\mathrm{B}_{12}$ vitamini yeterli alım düzeyi ise $4.5 \mathrm{mcg}$ /gün'dür $(8,44)$.

D Vitamini: Kalsiyum homeostazı ve osteoid mineralizasyonundan, steroid hormon etkisi ile epigenetik değişimlere dek, geniş yelpazede birçok işleve sahip olan D vitamini, gebelik süresince kritik öneme sahip bir diğer mikro besin ögesidir $(55,56)$. Gebelikte, D vitamininin homeostazisi büyük ölçüde değiştirmektedir. Ancak, artan gereksinim ve D vitamini sentezinin birçok faktöre (mevsim, ten rengi, yaş vb.) bağlı oluşu nedeni ile yetersizlik riski yüksektir (57).

Gözlemsel çalışmalara göre, gebelikte D vitamini yetersizliği; preeeklampsi, gestasyonel diabetes mellitus (GDM), ayına göre daha erken doğum (SGA) ve bakteriyel vajinozis gibi olumsuz sonuçlar ile korelasyon göstermektedir $(55,58$ $60)$. Yetersizliğin fetal etkileri incelendiğinde; intrauterin büyüme geriliği (IUGR), doğumsal rikets, otoimmün hastaliklar (tip 1 diyabet, alerjik rinit vb.) ve postnatal dönemde merkezi sinir sistemine ilişkin hastalıklar (otizm, multiple skleroz, epilepsi vb.) için riskin arttı̆̆ 62).

Maternal D vitamini (25-OH-D) optimum değeri için literatürde fikir birliği yoktur. Bu değer Tip Enstitüsü’ne (Institute of Medicine: IOM) göre $50 \mathrm{nmol} / \mathrm{L}(20 \mathrm{ng} / \mathrm{mL})$, Endokrin Derneği'ne (Endocrine Society) göre $75 \mathrm{nmol} / L$ 'dir. Dolaylı olarak, gebelikte D vitamini için önerilen yeterli alım düzeyi de farklılık göstermektedir; IOM’a göre $600 \mathrm{IU} /$ gün (15 mcg/gün) iken Endokrin Derneği'ne göre 15002000 IU'dir $(63,64)$. Önerilen dozların sağlanmasında tercih edilen yöntemlerden biri besin desteği uygulamalarıdır (65). Ülkemizde, Sağlık Bakanlığı tarafından, 'Gebelere D Vitamini Destek Programı" kapsamında; gebeliğin 12. haftasından başlamak üzere, gebelik boyunca ve postpartum 6 ay süresince $1200 \mathrm{IU} /$ gün D vitamini desteği uygulanmaktadır (66). Bu bağlamda DSÖ önerilerine bakıldığında; yeterli alım düzeyi 200 IU/gün olup, yetersizlik tespit edildiği takdirde daha yüksek dozlarda desteğin başlayabileceği; ancak rutin destek için kanıtların yetersiz olduğu belirtilmektedir (67). Gebelikte D vitamini desteği üzerine yapılmış bir sistematik derlemede; desteğin plaseboya göre olumlu etkisi onaylanmış, ancak optimal dozun belirsizliği ve literatürdeki çalışmalarda yan etkilere ilişkin verilerin yetersiz olduğunun altı çizilmiştir (68).

Gebeler için D vitamini tolere edilebilir üst alım düzeyi IOM’a göre 4.000 IU/gün iken; Endokrin Derneğine göre 10.000 IU/gün'dür $(63,64)$. İki kurumun, özellikle tolere edilebilir üst alım düzeyi konusunda, sunduğu farklı öneriler klinik uygulamalarda intoksisite riski için belirsizlik oluşturmaktadır. İntoksisite, ancak aşırı doz besin desteği ile mümkündür; bu durumun sonucunda anoreksi, poliüri ve aritmi gibi spesifik olmayan semptomlar, hiperkalsemi ilişkili yumuşak doku kalsifikasyonu ve teratojenite görülebilir (65, 69). Günlük 10.000 IU dozda minimal toksisite bildirilmiş olup, 20.000 IU üzerinde belirginleşmektedir (67). Gebelerde $\mathrm{D}$ vitamini desteği kullanımına ilişkin az sayıda güvenilirlik çalışması bulunmaktadır. Tek doz 70.000 IU D vitamini desteği kullanılan bir çalışmada, farmakodinamiğin gebeliğin 27 ila 30. haftalarındaki kadınlar ve gebe olmayan kadınlarda benzer olduğu bildirilmiştir (70).

D vitamini desteği dozuna ilişkin randomize kontrollü çalışmalara göre; gebeliğin 12-16. haftalarından gebelik sonuna dek 4.000 IU/gün destek uygulandığında, hiperkalse- 
mi veya hiperkalsiüri rapor edilmemekle birlikte, $4000 \mathrm{IU} /$ gün dozun güvenli ve serum 25-OH-D düzeyi için etkin doz olduğu bildirilmiştir (56,70,71). Başka bir çalışmada, son trimesterde (26-29. haftalar arasi) haftalı tek doz 35.000 IU’nun plaseboya karşı güvenilirliği incelemiş ve herhangi bir toksisite belirtisi gözlemlenmemiş, gebelik sonuçları gruplar arasında farklılık göstermemiştir (70). Literatürde D vitamini desteğinin uygulama prensipleri hakkında fikir birliği bulunmamaktadır.

Bugüne dek yapılan çalışmalarda, yüksek dozda D vitamini desteğinin nispeten kısa süreli ( $<6$ ay) etkilerine ilişkin veriler bulunmaktadır. Her ne kadar 10.000 IU altında $\mathrm{D}$ vitamini desteğinin, toksisite semptomları bildirilmese de hiperkalsemiye dayalı hızlı gelişen semptomların ötesinde, steroid hormon etkileri sebebi ile henüz yeterince araştırılmamıştır ve özellikle epigenetik ile ilişkili riskleri de beraberinde getirebileceği endişesi kayda değerdir $(69,72)$.

İyot: Fetüsün tiroid bezi gestasyonun 10-12. haftalarında gelişir ve hormon üretimi ve salınımı açısından 18-20. haftalar arasında fonksiyonellik kazanır. Bu nedenle, gebeliğin ilk yarısında fetusün nöronal gelişimi, özellikle miyelinasyonu, maternal tiroid hormonuna bağımlıdır. Gebelik sürecinde östrojen etkilerine bağlı olarak tiroksin bağlayıcı globulin seviyeleri artar. Gebeliğin ilk trimesterinde, insan koryonik gonadotropin hormonu tiroid uyarıcı hormon reseptörlerini uyarır. Bu hormonal değişiklikler sonucu maternal tiroid hormonu üretiminde $\% 50$ artış görülür. Tiroid hormonları embriyonik yaşamın ilk haftalarından başlayarak beyin gelişimi başta olmak üzere embriyonun genel büyüme ve gelişimi için çok önemlidir. Bununla birlikte gebeliğin ilk trimesterinden başlayarak artan glomerüler filtrasyon hızı tiroid hormon sentezi için gerekli olan iyotun renal klerensini \%30-50 arttırır. Ayrıca maternal kandan fetüse transplasental iyot geçişi de yaşanmaktadır. Tüm bu değişiklikler gebelikte iyot gereksiniminin artmasına yol açtığı için gebeler iyot yetersizliği hastalıkları açısından riskli bir grup olarak görülmektedir $(73,74)$.

Gebe için idrar iyot konsantrasyonu ortalamasının $<150$ $\mathrm{mcg} / \mathrm{L}$ olması iyot yetersizliği, $<20 \mathrm{mcg} / \mathrm{L}$ olması ise ciddi iyot yetersizliği olarak değerlendirilmektedir (73). İyot yetersizliği hem gebe hem de bebek üzerinde; prematüre doğum, düşük, mental retardasyon, konjenital anormali, guatr, hipotroidizm, yetersiz büyüme ve kognitif problemler gibi birçok olumsuz sonuca yol açmaktadır. Ciddi ve orta derecede iyot yetersizliğinin görüldüğü bölgelerde gebenin iyot yetersizliğ ile çocuğun nörokognitif gelişimi arasında ilişki olduğu gösterilmiştir (75). Bu bölgelerde gebelere verilen iyot desteğinin çocukların nörogelişimi üzerinde olumlu etkiler sağladı$\breve{g}_{1}$ da belirlenmiştir $(76,77)$. Çok hafif iyot yetersizliğinin bile çocuğun zekâ düzeyi ve işitsel fonksiyonunda bozukluklara yol açabileceğini gösteren kanitlar mevcuttur $(75,78)$.

İyot yetersizliği hastalıklarını önlemek amaçlı evrensel olarak tuzun iyotlanması programı ile birlikte birçok gelişme kaydedilmesine rağmen bazı bölgelerde bu yetersizlik görülmeye devam etmektedir (79). Yeterli iyot alımı; iyottan zen- gin besin tüketimi arttırılarak, iyotlu tuz tercih edilerek veya iyot destekleri kullanılarak sağlanabilir (80). DSÖ, tuz iyodizasyonunun mümkün olmadığ 1 veya yetersiz olduğu ciddi iyot eksikliği olan bölgelerde; gebelere, emziklilere, üreme çağındaki kadınlara ve iki yaşın altındaki çocuklara günlük olarak düşük dozlarda iyot takviyesi veya her 6-12 ayda bir yüksek dozda oral yolla iyotlu yağ verilmesini önermektedir (81). Ayrıca besinsel iyot yetersizliğinin yaşandığ ${ }_{1}$ ve iyotlu tuz kullanan ev oranının \%90'nın altında olduğu bölgelerde de gebeler gibi bazı hassas gruplarda iyot desteğinin kullanılması önerilmektedir (82). Fakat iyot yetersizliğinin görülmediği gelişmiş ülkelerde bile gebeliğin erken dönemlerinde iyot desteği yaygın olarak verilmekte ve gerekçe olarak da iyot yetersizliği sonucunda görülebilecek risklerin, iyotun fazla alınması sonucu görülebilecek risklerden daha fazla olması gösterilmektedir (83). Ancak iyot alımındaki artış genel popülasyon ve üreme çağındaki kadınlarda subklinik ve aşikâr hipotiroidizm prevalansındaki artış ile ilişkilendirilmiştir (84). Rebagliato ve arkadaşlarının yaptığ tun yeterli olduğu veya hafif yetersizliğin görüldüğü bölgelerde gebeliğin ilk yarısında verilen iyot desteğinin annenin tiroid disfonksiyonuna yol açtığı belirlenmiştir (85). Bir başka çalışmada da gebeliğin sonlarında görülen tiroid disfonksiyonu aşırı iyot alımı ile ilişkilendirilmiştir (80). Bunların yanı sıra hafif iyot yetersizliğinin görüldüğü gebe kadınlarda iyot desteğinin, anne ve bebeğin serum trioglobülinleri ve tiroid volümleri üzerinde olumlu etkileri olduğu, fakat total ve serbest tiroid hormon konsantrasyonları üzerinde herhangi bir etkisinin olmadığı da gösterilmiştir (86).

İdrar iyot konsantrasyonu ortalamas1 $109 \mathrm{mcg} / \mathrm{L}$ olan olan gebelerin randomize olarak; iyotlu tuz, $200 \mathrm{mcg}$ ve $300 \mathrm{mcg}$ potasyum iyodür (KI)/gün almak üzere üç gruba ayrıldığı bir çalışmada, gebelik sürecinde görülen tiroid fonksiyonlarının gebelikte alınan iyot formu veya dozu ile ilişkili olmadığı ancak gebelikten önceki iyotlu tuz tüketimi ile ilişkili olduğu belirlenmiştir. Gebeliğin en az bir yıl öncesinden iyotlu tuz kullanan gebelerin, kullanmayan gebelere göre gebeliğin son trimesterinde anlamlı olarak daha düşük tiroid volümlerine ve gebeliğin ilk ve son trimesterlerinde anlamlı olarak daha yüksek idrar iyot konsantrasyonuna sahip olduğu görülmüştür. Ayrıca gebelere verilen iyot destekler ile bebeklerin nörokognitif gelişimleri arasında ilişki saptanmamıştır (80). Fakat başka bir çalışmada; idrar iyot konsatrasyonu ortalaması $80 \mathrm{mcg} / \mathrm{L}$ olan gebelere verilen $300 \mathrm{mcg} \mathrm{KI} /$ gün destek, iyot desteği verilmeyenlerin bebekleri ile kıyaslandığında, iyot desteği alan grubun bebeklerinin yaşamın birinci ve ikinci yıllarında yapılan psikomotor testlerde daha yüksek puanlar almasını sağlamıştır (87). Bu çalışmalar birlikte değerlendirildiğinde gebelere verilen iyot desteğinin çocukların nörokognitif fonksiyonu üzerindeki etkisinin gebenin iyot durumuna bağlı olarak değiştiği sonucuna varılabilir. Gebelikte iyot veya iyot içeren çoklu vitamin desteği alımının etkilerini inceleyen bir çalışmada; annenin idrar iyot konsantrasyonu, iyotlu tuz tüketimi ve yüksek iyot içeren besinlerin tüketimi ile bebeğin nörogelişimi arasında ilişki bulunamamıştır. Fa- 
kat gebelikte $<100 \mathrm{mcg} /$ gün iyot desteği alanlara kıyasla $\geq 150$ $\mathrm{mcg} /$ gün iyot desteği alanların bebeklerinin bir yaşındaki psikomotor gelişim indeksinin 5,2 puan daha düşük olduğu ve bu indeks puanının $<85$ olma riskinin 1,8 kat arttığı saptanmıştır. Cinsiyete göre analizler tekrarlandığında bu risklerin sadece kız çocuklarında görüldüğü belirlenmiştir (84).

Bazı ülkelerde görülen iyot yetersizliği; iyot, diyetteki iyot kaynakları ve iyot yetersizliğinin önemi ile ilgili eğitim programlarının eksikliği ve uygun olmayan iyot uygulamalarından kaynaklanmaktadır (88). İyotlu tuzla ilgili kitlesel bir medya kampanyası başlatılmış olmasının, ülkemiz kadınlarının iyotlu tuz ile ilgili bilgi, tutum ve davranışlarını olumlu yönde etkilediği görülmüştür (89). İran'da yapılan çok merkezli bir çalışmada gebelere iyot ile ilgili verilen eğitim ve broşürlerin iyot ile ilgili bilgi, tutum ve davranışlarda anlamlı gelişmeler sağladığı, fakat bu gelişmelerin kullandıkları tuzların iyot içeriğine ve idrar iyot konsantrasyonlarına yansımadığı bildirilmiştir. Çalışmaya katılan gebeler sosyal medyadan hem iyotlu tuz tüketmeleri hem de tuz tüketimini sınırlandırmaları yönünde edindikleri bilgilerin kafa karıştırıcı olduğunu ifade etmişlerdir. Ayrıca piyasada bulunan iyotlu tuzların, iyotlu tuz olarak adlandırılabilmesi için gerekli olan 20-40 mg/kg iyot aralığının alt sınırından zenginleştirildiği ve gebeler için önerilen iyot alımını sağlamak için $40 \mathrm{mg}$ iyot ile zenginleştirilmiş tuzdan 6 gr tüketmeleri gerektiği vurgulanmıştır (88). Özellikle iyot yetersizliği görülen ve iyotun asıl kaynağının iyotlu tuz olduğu ülkelerde, hükümetler tuzların iyotla zenginleştirilmesi ile ilgili izlem stratejileri geliştirmelidir.

Gebelikte iyot için önerilen yeterli alım düzeyi, DSÖ’ye göre $250 \mathrm{mcg} /$ gün, IOM’ye göre $220 \mathrm{mcg} /$ gün ve TÜBER’e göre $200 \mathrm{mcg} /$ gün'dür. Gebeler için tolere edilebilir üst alım düzeyi IOM'ye göre 1100 mcg/gün iken TÜBER'de 600 mcg/ gün olarak belirlenmiştir $(8,54,90)$. Gebelikte verilen iyot desteğinin ciddi iyot yetersizliğinde olumlu etkileri olduğu iyi bilinmesine rağmen hafif-orta iyot yetersizliğinin görüldüğü durumlardaki etkisi tam olarak bilinmemektedir (74). Yakın zamanlı sistematik bir derlemede; gebelik öncesi, sırası veya sonrasında rutin iyot desteği verilmesinin yararları ve zararları ile ilgili henüz yeterli verinin olmadığı ve rutin olarak iyot desteği önerilmeden önce, iyot desteklerinin uzun süreli etkinlikleri ve güvenliği ile ilgili daha fazla çalışmaya ihtiyaç duyulduğu belirtilmiştir (79).

Sonuç ve Öneriler: Gebelik sürecinde hem anne hem de fetüste meydana gelen değişimler sonucunda gebenin enerji ve besin ögesi ihtiyaçları artmaktadır. Artan besin ögesi ihtiyaçlarını karşılayamayan gebeler ve bebekleri kısa ve uzun dönemde birçok olumsuz sağlık sonuçları ile karşılaşmaktadır. Bu sağlık problemlerinden korunmak amaçlı önerilen besin destekleri özellikle ciddi yetersizlik durumlarında olumlu sonuçlar ile ilişkilendirilmiş olsa da hafif-orta yetersizlik durumlarında veya ortada bir yetersizlik durumu yok iken gelişigüzel besin desteği kullanımında riskler oluşturabileceği göz önünde bulundurulmalıdır. Çalışmalarda folik asit fazlalığının kanserojeniteyi tetikleyebileceği, çinko emilimini olumsuz etkileyebileceği, B12 vitamini eksikliğini bir noktaya kadar kompanse ederek tanıda ve müdahalede gecikmelere yol açabileceği, astım, alerji ve otizm riski ile ilişkili olabileceğine değinilmiştir. Yüksek dozda D vitamini alımının hiperkalsemi ile ilişkili semptomların yanısıra, henüz öngörülemeyen epigenetik değişimlere neden olması mümkündür. Artan iyot alımının gebenin tiroid disfonksiyonuna ve gebelikteki subklinik ve aşikâr hipotiroidizm prevalansında artışa yol açabileceği ve bebeğin psikomotor gelişimini olumsuz etkileyebileceği bildirilmektedir. Sonuç olarak besin desteği kullanımı önerilmeden önce toplumun, mümkünse bireyin, o besin ögesi açısından durumu göz önünde bulundurulmalı, beslenme alışkanlıkları ve besin tüketim miktarları sorgulanmalı ve sadece gerekli görüldügü koşullarda besin desteği kullanımı hekimler tarafından önerilmelidir.

Çıkar Çatışması ve Finansman Beyanı: Bu çalışmada çıkar çatışması yoktur ve finansman desteği alınmamıştır.

Araştırmacıların Katkı Oranı Beyan Özeti: Yazarlar makaleye eşit katkı sağlamış olduklarını beyan ederler.

\section{KAYNAKLAR}

1. Richard K, Holland O, Landers K, Vanderlelie JJ, Hofstee $\mathrm{P}$, Cuffe JS, et al. Effects of maternal micronutrient supplementation on placental function. Placenta. 2017;54:3844.

2. Gernand AD, Schulze KJ, Stewart CP, West Jr KP, Christian P. Micronutrient deficiencies in pregnancy worldwide: health effects and prevention. Nature Reviews Endocrinology. 2016;12(5):274.

3. Berti C, Biesalski H, Gärtner R, Lapillonne A, Pietrzik $\mathrm{K}$, Poston L, et al. Micronutrients in pregnancy: current knowledge and unresolved questions. Clinical nutrition. 2011;30(6):689-701.

4. Christian P, Stewart CP. Maternal micronutrient deficiency, fetal development, and the risk of chronic disease. The Journal of nutrition. 2010;140(3):437-445.

5. Ho A, Flynn AC, Pasupathy D. Nutrition in pregnancy. Obstetrics, Gynaecology \& Reproductive Medicine. 2016;26(9):259-264.

6. Procter SB, Campbell CG. Position of the Academy of Nutrition and Dietetics: nutrition and lifestyle for a healthy pregnancy outcome. Journal of the Academy of Nutrition and Dietetics. 2014;114(7):1099-1103.

7. Plećaš D, Plešinac S, Kontić-Vučinić O. Nutrition in pregnancy: basic principles and recommendations. Srpski arhiv za celokupno lekarstvo. 2014;142(1-2):125-130.

8. T.C. Sağlık Bakanlı̆̆ı. Türkiye Beslenme Rehberi (TÜBER): T.C. Sağlık Bakanlığı, Türkiye Halk Sağlığı Kurumu, 2015. Erişim Adresi:https://dosyasb.saglik.gov.tr/ Eklenti/10915,tuber-turkiye-beslenme-rehberipdf.pdf.

9. World Health Organization (WHO). WHO recommendation on daily oral iron and folic acid supplementation 2016. Erişim Adresi: https://www.who.int/elena/titles/ guidance_summaries/daily_iron_pregnancy/en/.

10. EFSA Panel on Dietetic Products, Nutrition and Allergies, 2014. Scientific Opinion on Dietary Reference Values for folate. EFSA Journal 2014; 12 (11): 3893. 
11. Antony AC. In utero physiology: role of folic acid in nutrient delivery and fetal development. The American journal of clinical nutrition. 2007;85(2):598-603.

12. Khan KM, Jialal I. Folic acid (folate) deficiency. StatPearls [Internet]: StatPearls Publishing; 2019.

13. Jing Y, Zheng YZ, Cao LJ, Liu YY, Wen L, Huang GW. Periconceptional folic acid supplementation in Chinese women: a cross-sectional study. Biomedical and Environmental Sciences. 2017;30(10):737-748.

14. Obeid R, Murphy M, Solé-Navais P, Yajnik C. Cobalamin status from pregnancy to early childhood: lessons from global experience. Advances in Nutrition. 2017;8(6):971979.

15. Aksu H, Sevil Ü, Yurtsev E, Güvendiren G. Nöral tüp defektleri ve folik asit. Maltepe Üniversitesi Hemşirelik Bilim ve Sanat Dergisi. 2010;2:1992.

16. Li K, Wahlqvist ML, Li D. Nutrition, one-carbon metabolism and neural tube defects: a review. Nutrients. 2016;8(11):741.

17. Gaskins AJ, Rich-Edwards JW, Hauser R, Williams PL, Gillman MW, Ginsburg ES, et al. Maternal prepregnancy folate intake and risk of spontaneous abortion and stillbirth. Obstetrics and gynecology. 2014;124(1):23-31.

18. Forges T, Monnier-Barbarino P, Alberto J, Gueant-Rodriguez R, Daval J, Gueant J. Impact of folate and homocysteine metabolism on human reproductive health. Human reproduction update. 2007;13(3):225-238.

19. Czeizel AE, Vereczkey A, Szabó I. Folic acid in pregnant women associated with reduced prevalence of severe congenital heart defects in their children: a national population-based case-control study. European Journal of Obstetrics \& Gynecology and Reproductive Biology. 2015;193:34-39.

20. Mao B, Qiu J, Zhao N, Shao Y, Dai W, He X, et al. Maternal folic acid supplementation and dietary folate intake and congenital heart defects. PloS one. 2017;12(11):e0187996.

21. Fekete K, Berti C, Cetin I, Hermoso M, Koletzko BV, Decsi T. Perinatal folate supply: relevance in health outcome parameters. Maternal \& child nutrition. 2010;6(Suppl 2):23-38

22. Rosenquist TH. Folate, homocysteine and the cardiac neural crest. Developmental Dynamics. 2013;242(3):201218.

23. Cantarella CD, Ragusa D, Giammanco M, Tosi S. Folate deficiency as predisposing factor for childhood leukaemia: a review of the literature. Genes \& nutrition. 2017;12(1):14.

24. Duthie SJ. Folate and cancer: how DNA damage, repair and methylation impact on colon carcinogenesis. Journal of inherited metabolic disease. 2011;34(1):101-109.

25. Figueiredo JC, Grau MV, Haile RW, Sandler RS, Summers RW, Bresalier RS, et al. Folic acid and risk of prostate cancer: results from a randomized clinical trial. Journal of the National Cancer Institute. 2009;101(6):432-435.

26. Charles D, Ness AR, Campbell D, Smith GD, Hall MH. Taking folate in pregnancy and risk of maternal breast cancer. Bmj. 2004;329(7479):1375-1376.

27. Hotz C, Brown KH. International Zinc Nutrition Con- sultative Group (IZiNCG). Technical Document \#1. Assessment of the risk of zinc deficiency in populations and options for its control. Food and Nutrition Bulletin. 2004;25:S91-S203.

28. Ghishan FK, Said HM, Wilson PC, Murrell JE, Greene HL. Intestinal transport of zinc and folic acid: a mutual inhibitory effect. The American journal of clinical nutrition. 1986;43(2):258-262.

29. Green TJ, Skeaff CM, Whiting SJ, Gibson RS. Effect of folic acid supplementation on plasma zinc concentrations of young women. Nutrition. 2003;19(6):522-523.

30. Hansen M, Samman S, Madsen LT, Jensen M, Sørensen SS, Sandström B. Folic acid enrichment of bread does not appear to affect zinc absorption in young women. The American journal of clinical nutrition. 2001;74(1):125129.

31. Smulders Y, Smith D, Kok R, Teerlink T, Swinkels D, Stehouwer C, et al. Cellular folate vitamer distribution during and after correction of vitamin B12 deficiency: a case for the methylfolate trap. British journal of haematology. 2006;132(5):623-629.

32. Cuskelly GJ, Mooney KM, Young IS. Folate and vitamin B 12: friendly or enemy nutrients for the elderly*: Symposium on 'Micronutrients through the life cycle'. Proceedings of the Nutrition Society. 2007;66(4):548-558.

33. Wiens $\mathrm{D}$, DeSoto MC. Is high folic acid intake a risk factor for autism? - a review. Brain sciences. 2017;7(11):149.

34. Gao Y, Sheng C, Xie R-h, Sun W, Asztalos E, Moddemann D, et al. New perspective on impact of folic acid supplementation during pregnancy on neurodevelopment/autism in the offspring children-a systematic review. PloS one. 201611(11)11(11):e0165626.

35. Kiefte-de Jong JC, Timmermans S, Jaddoe VW, Hofman A, Tiemeier H, Steegers EA, et al. High circulating folate and vitamin B-12 concentrations in women during pregnancy are associated with increased prevalence of atopic dermatitis in their offspring. The Journal of nutrition. 2012;142(4):731-738.

36. Li W, Xu B, Cao Y, Shao Y, Wu W, Zhou J, et al. Association of maternal folate intake during pregnancy with infant asthma risk. Scientific reports. 2019;9(1):1-8.

37. Whitrow MJ, Moore VM, Rumbold AR, Davies MJ. Effect of supplemental folic acid in pregnancy on childhood asthma: a prospective birth cohort study. American journal of epidemiology. 2009;170(12):1486-1493.

38. Yang L, Jiang L, Bi M, Jia X, Wang Y, He C, et al. High dose of maternal folic acid supplementation is associated to infant asthma. Food and Chemical Toxicology. 2015;75:88-93.

39. Martinussen MP, Risnes KR, Jacobsen GW, Bracken MB. Folic acid supplementation in early pregnancy and asthma in children aged 6 years. American journal of obstetrics and gynecology. 2012;206(1):1-7.

40. Magdelijns FJ, Mommers M, Penders J, Smits L, Thijs C. Folic acid use in pregnancy and the development of atopy, asthma, and lung function in childhood. Pediatrics. 2011;128(1):135-144.

41. Bekkers MB, Elstgeest LE, Scholtens S, Haveman-Nies 
A, de Jongste JC, Kerkhof M, et al. Maternal use of folic acid supplements during pregnancy, and childhood respiratory health and atopy. European Respiratory Journal. 2012;39(6):1468-1474.

42. Dunstan J, West C, McCarthy S, Metcalfe J, Meldrum S, Oddy W, et al. The relationship between maternal folate status in pregnancy, cord blood folate levels, and allergic outcomes in early childhood. Allergy. 2012;67(1):50-57.

43. Stabler SP. Vitamin B12 deficiency. New England Journal of Medicine. 2013;368(2):149-60.

44. EFSA Panel on Dietetic Products, Nutrition and Allergies. Scientific opinion on dietary reference values for cobalamin (vitamin B12). EFSA Journal. 2015;13(7):4150.

45. Simpson JL, Bailey LB, Pietrzik K, Shane B, Holzgreve W. Micronutrients and women of reproductive potential: required dietary intake and consequences of dietary deficiency or excess. Part I-Folate, Vitamin B12, Vitamin B6. The Journal of Maternal-Fetal \& Neonatal Medicine. 2010;23(12):1323-1343.

46. Coşkun A, Özdemir Ö. Gebelikte vitamin-mineral kullanımı ve beslenmenin irdelenmesi. Türk Jinekoloji ve Obstetrik Derneği Dergisi. 2009;6(3):155-170.

47. Aslaner H. Vitamin B12 Eksikliği ve Tedavisi. Klinik Tip Aile Hekimliği.2018;10(6):18-24.

48. Acılmis YG, Dikensoy E, Kutlar AI, Balat O, Cebesoy FB, Ozturk E, et al. Homocysteine, folic acid and vitamin B12 levels in maternal and umbilical cord plasma and homocysteine levels in placenta in pregnant women with preeclampsia. Journal of Obstetrics and Gynaecology Research. 2011;37(1):45-50.

49. Muthayya S, Dwarkanath P, Mhaskar M, Mhaskar R, Thomas A, Duggan C, et al. The relationship of neonatal serum vitamin B 12 status with birth weight. Asia Pacific journal of clinical nutrition. 2006;15(4):538-43.

50. Hogeveen M, Blom HJ, Den Heijer M. Maternal homocysteine and small-for-gestational-age offspring: systematic review and meta-analysis. The American journal of clinical nutrition. 2012;95(1):130-136.

51. Obeid R, Oexle K, Rißmann A, Pietrzik K, Koletzko B. Folate status and health: challenges and opportunities. Journal of perinatal medicine. 2016;44(3):261-268.

52. Puri M, Kaur L, Walia GK, Mukhopadhhyay R, Sachdeva MP, Trivedi SS, et al. MTHFR C677T polymorphism, folate, vitamin B12 and homocysteine in recurrent pregnancy losses: a case control study among North Indian women. Journal of perinatal medicine. 2013;41(5):549554.

53. Morales-Gutierrez J, Díaz-Cortés S, Montoya-Giraldo MA, Zuluaga AF. Toxicity induced by multiple high doses of vitamin B12 during pernicious anemia treatment: a case report. Clinical Toxicology. 2020;58(2):129-131.

54. World Health Organization/Food and Agriculture Organization (WHO/FAO) Vitamin and mineral requirements in human nutrition: report of a joint FAO/WHO expert consultation, 2004. Erişim Adresi: https://apps. who.int/iris/handle/10665/42716

55. Hu L, Zhang Y, Wang X, You L, Xu P, Cui X, et al. Maternal Vitamin D Status and Risk of Gestational Diabetes: a Meta-Analysis. Cell Physiol Biochem. 2018;45(1):291300.

56. Hollis BW, Johnson D, Hulsey TC, Ebeling M, Wagner CL. Vitamin D supplementation during pregnancy: double-blind, randomized clinical trial of safety and effectiveness. Journal of bone and mineral research. 2011;26(10):2341-2357.

57. Karras SN, Wagner CL, Castracane VD. Understanding vitamin $\mathrm{D}$ metabolism in pregnancy: from physiology to pathophysiology and clinical outcomes. Metabolism. 2018;86:112-23.

58. Amegah AK, Klevor MK, Wagner CL. Maternal vitamin $\mathrm{D}$ insufficiency and risk of adverse pregnancy and birth outcomes: a systematic review and meta-analysis of longitudinal studies. PLoS One. 2017;12(3).

59. Arnold DL, Enquobahrie DA, Qiu C, Huang J, Grote N, VanderStoep A, et al. Early pregnancy maternal vitamin D concentrations and risk of gestational diabetes mellitus. Paediatric and perinatal epidemiology. 2015;29(3):200210.

60. Wang H, Xiao Y, Zhang L, Gao Q. Maternal early pregnancy vitamin $\mathrm{D}$ status in relation to low birth weight and small-for-gestational-age offspring. The Journal of steroid biochemistry and molecular biology. 2018;175:146-150.

61. Sørensen IM, Joner G, Jenum PA, Eskild A, Brunborg C, Torjesen PA, et al. Vitamin D-binding protein and 25hydroxyvitamin $\mathrm{D}$ during pregnancy in mothers whose children later developed type 1 diabetes. Diabetes/metabolism research and reviews. 2016;32(8):883-890.

62. Gürz AA, İğde FAA, Dikici MF. D Vitamininin Fetal ve Maternal Etkileri. Konuralp Medical Journal/Konuralp Tip Dergisi. 2015;7(1):69-75.

63. Rosen CJ, Abrams SA, Aloia JF, Brannon PM, Clinton SK, Durazo-Arvizu RA, et al. IOM committee members respond to Endocrine Society vitamin D guideline. The Journal of Clinical Endocrinology \& Metabolism. 2012;97(4):1146-1152.

64. Holick MF, Binkley NC, Bischoff-Ferrari HA, Gordon CM, Hanley DA, Heaney RP, et al. Evaluation, treatment, and prevention of vitamin D deficiency: an Endocrine Society clinical practice guideline. The Journal of Clinical Endocrinology \& Metabolism. 2011;96(7):1911-1930.

65. Pludowski P, Holick MF, Grant WB, Konstantynowicz J, Mascarenhas MR, Haq A, et al. Vitamin D supplementation guidelines. The Journal of steroid biochemistry and molecular biology. 2018;175:125-35.

66. T.C. Sağlık Bakanlığı. Gebelere D Vitamini Destek Programı 2011.Erişim Adresi: https://www.saglik.gov.tr/ TR,11158/gebelere-d-vitamini-destek-programi.html.

67. World Health Organization (WHO). Vitamin D supplementation in pregnant women 2012. Erişim Adresi: https://apps.who.int/iris/bitstream/handle/10665/85313/9789241504935_eng.pdf.

68. Palacios C, Kostiuk LK, Peña-Rosas JP. Vitamin D supplementation for women during pregnancy. Cochrane Database of Systematic Reviews. 2019;7(7):CD008873.

69. Institute of Medicine (IOM). Vitamin D Fact Sheet for Health Professionals 2010. Erişim Adresi: https://ods.od. 
nih.gov/factsheets/VitaminD-HealthProfessional/\#en26.

70. Roth DE, Al Mahmud A, Raqib R, Akhtar E, Perumal N, Pezzack B, et al. Randomized placebo-controlled trial of high-dose prenatal third-trimester vitamin D3 supplementation in Bangladesh: the AViDD trial. Nutrition journal. 2013;12(1):47.

71. Enkhmaa D, Tanz L, Ganmaa D, Enkhtur S, Oyun-Erdene B, Stuart J, et al. Randomized trial of three doses of vitamin $\mathrm{D}$ to reduce deficiency in pregnant Mongolian women. EBioMedicine. 2019;39:510-519.

72. De-Regil LM, Palacios C, Lombardo LK, Peña-Rosas JP. Vitamin D supplementation for women during pregnancy. Cochrane Database of Systematic Reviews. 2016;(1):CD008873.

73. Trofimiuk-Mudlner M, Hubalewska-Dydejczyk A. Iodine deficiency and iodine prophylaxis in pregnancy. Recent patents on endocrine, metabolic \& immune drug discovery. 2016;10(2):85-95.

74. Chittimoju SB, Pearce EN. Iodine deficiency and supplementation in pregnancy. Clinical obstetrics and gynecology. 2019;62(2):330-338.

75. Hamrosi MA, Wallace EM, Riley MD. Iodine status in pregnant women living in Melbourne differs by ethnic group. Asia Pacific journal of clinical nutrition. 2005;14(1).

76. Qian M, Wang D, Watkins WE, Gebski V, Yan YQ, Li M, et al. The effects of iodine on intelligence in children: a meta-analysis of studies conducted in China. Asia Pacific journal of clinical nutrition. 2005;14(1):32-42.

77. Zimmermann MB. Iodine deficiency in pregnancy and the effects of maternal iodine supplementation on the offspring: a review. The American journal of clinical nutrition. 2009;89(2):668-672.

78. Hynes KL, Otahal P, Hay I, Burgess JR. Mild iodine deficiency during pregnancy is associated with reduced educational outcomes in the offspring: 9-year follow-up of the gestational iodine cohort. The Journal of Clinical Endocrinology \& Metabolism. 2013;98(5):1954-1962.

79. Harding KB, Peña-Rosas JP, Webster AC, Yap CM, Payne BA, Ota E, et al. Iodine supplementation for women during the preconception, pregnancy and postpartum period. Cochrane Database of Systematic Reviews. 2017;3(3):CD011761.

80. Santiago P, Velasco I, Muela JA, Sánchez B, Martínez J, Rodriguez A, et al. Infant neurocognitive development is independent of the use of iodised salt or iodine supplements given during pregnancy. British journal of nutrition. 2013;110(5):831-839.

81. Secretariat W, Andersson M, De Benoist B, Delange F, Zupan J. Prevention and control of iodine deficiency in pregnant and lactating women and in children less than 2-years-old: conclusions and recommendations of the Technical Consultation. Public health nutrition. 2007;10(12A):1606-1611.

82. Leung AM, Pearce EN, Braverman LE. Iodine nutrition in pregnancy and lactation. Endocrinology and Metabolism Clinics. 2011;40(4):765-777.

83. Becker DV, Braverman LE, Delange F, Dunn JT, Franklyn
JA, Hollowell JG, et al. Iodine supplementation for pregnancy and lactation-United States and Canada: recommendations of the American Thyroid Association. Thyroid. 2006;16(10):949-951.

84. Murcia M, Rebagliato M, Iniguez C, Lopez-Espinosa M-J, Estarlich M, Plaza B, et al. Effect of iodine supplementation during pregnancy on infant neurodevelopment at 1 year of age. American journal of epidemiology. 2011;173(7):804-812.

85. Rebagliato M, Murcia M, Espada M, Álvarez-Pedrerol M, Bolúmar F, Vioque J, et al. Iodine intake and maternal thyroid function during pregnancy. Epidemiology. 2010:62-9.

86. Zimmermann MB. The adverse effects of mild-to-moderate iodine deficiency during pregnancy and childhood: a review. Thyroid. 2007;17(9):829-835.

87. Velasco I, Carreira M, Santiago P, Muela JA, García-Fuentes E, Sanchez-Munoz B, et al. Effect of iodine prophylaxis during pregnancy on neurocognitive development of children during the first two years of life. The Journal of Clinical Endocrinology \& Metabolism. 2009;94(9):32343241.

88. Amiri P, Hamzavi Zarghani N, Nazeri P, Ghofranipour F, Karimi M, Amouzegar A, et al. Can an educational intervention improve iodine nutrition status in pregnant women? A randomized controlled trial. Thyroid. 2017;27(3):418-425.

89. Çan G, Ökten A, Green J. The role of local mass media in promoting the consumption of iodized table salt. Health Education Research. 2001;16(5):603-607.

90. Institute of Medicine (IOM) Panel on Micronutrients. Dietary Reference Intakes for Vitamin A, Vitamin K, Arsenic, Boron, Chromium, Copper, Iodine, Iron, Manganese, Molybdenum, Nickel, Silicon, Vanadium, and Zinc. Washington (DC): National Academies Press (US); 2001. 8, Iodine. Erişim Adresi: https://www.ncbi.nlm.nih.gov/ books/NB 222323/ 